University of Montana

ScholarWorks at University of Montana

8-2001

\title{
Spatial and Temporal Variability in Nest Success of Snail Kites in Florida : A Meta-Analysis
}

\author{
Victoria J. Dreitz \\ University of Montana - Missoula, victoria.dreitz@cfc.umt.edu \\ Robert E. Bennetts \\ University of Florida \\ Brian Toland \\ Wiley M. Kitchens \\ University of Florida \\ Michael W. Collopy
}

Follow this and additional works at: https://scholarworks.umt.edu/wildbio_pubs

Part of the Life Sciences Commons

Let us know how access to this document benefits you.

\section{Recommended Citation}

Dreitz, Victoria J.; Bennetts, Robert E.; Toland, Brian; Kitchens, Wiley M.; and Collopy, Michael W., "Spatial and Temporal Variability in Nest Success of Snail Kites in Florida : A Meta-Analysis" (2001). Wildlife Biology Faculty Publications. 61.

https://scholarworks.umt.edu/wildbio_pubs/61

This Article is brought to you for free and open access by the Wildlife Biology at ScholarWorks at University of Montana. It has been accepted for inclusion in Wildlife Biology Faculty Publications by an authorized administrator of ScholarWorks at University of Montana. For more information, please contact scholarworks@mso.umt.edu. 


\title{
SPATIAL AND TEMPORAL VARIABILITY IN NEST SUCCESS OF SNAIL KITES IN FLORIDA: A META-ANALYSIS
}

\author{
Victoria J. Dreitz ${ }^{1,2,5}$, Robert E. Bennetts ${ }^{2,3}$, Brian Toland ${ }^{4,6}$, Wiley M. Kitchens ${ }^{2}$ \\ AND MichaEl W. COLLOPY ${ }^{3,7}$ \\ ${ }^{1}$ Department of Biology, University of Miami, P.O. Box 249118, Coral Gables, FL 33124 \\ ${ }^{2}$ Florida Cooperative Fish and Wildlife Research Unit, P.O. Box 110450, University of Florida, \\ Gainesville, FL 32611 \\ ${ }^{3}$ Department of Wildlife Ecology and Conservation, P.O. Box 110430, University of Florida, \\ Gainesville, FL 32611 \\ ${ }^{4}$ Florida Game and Fresh Water Fish Commission, Vero Beach, FL 32968
}

\begin{abstract}
Nesting success of Snail Kites (Rostrhamus sociabilis) in Florida is highly variable among years and locations, and hydrology is the most frequently reported explanatory factor. We conducted a meta-analysis to evaluate the extent of spatial and temporal variability in nesting success, and explicitly tested for the effects of annual minimum water levels. Data were obtained from six independent studies spanning 22 years and 11 wetlands. Our results indicated there was substantial spatial and temporal variability in nest success and that annual minimum water level, either as a categorical or continuous response, was not a significant source of this variation. Our results do not imply that low water levels do not influence nest success. Rather, they indicate that the number of nests affected by low water conditions was quite low $(<1 \%)$. A wetland area experiences low water once every 5 to 10 years, and seldom does such an event encompass the entire range of Snail Kites in Florida. During a low water event, kites are capable of moving to alternative locations. Thus, relatively few birds may exhibit low nest success as a result of low water events, and management aimed at preclusion of such events may be unnecessary and detrimental to maintenance of the habitat over long time scales.
\end{abstract}

Key words: endangered species, Everglades, Florida, meta-analysis, nest success, Rostrhamus sociabilis, Snail Kite.

Variabilidad Espacial y Temporal en el Éxito de Anidación de Rostrhamus sociabilis en Florida: Un Meta-Análisis

Resumen. El éxito de anidación de Rostrhamus sociabilis en Florida varía ampliamente entre años y localidades. La hidrología es el factor que se ha propuesto con mayor frecuencia para explicar dicha variabilidad. Llevamos a cabo un meta-análisis para evaluar la magnitud de la variabilidad espacial y temporal en el éxito de anidación y pusimos a prueba explícitamente el efecto de los niveles mínimos anuales de agua. Los datos fueron obtenidos de seis estudios independientes comprendiendo 22 años y 11 humedales. Nuestros resultados indicaron que hubo gran variación espacial y temporal en el éxito de anidación y que el nivel mínimo anual de agua (ya sea como una respuesta categórica o continua), no fue una fuente significativa de esta variación. Nuestros resultados no implican que niveles bajos de agua no afectan el éxito de anidación. En cambio, indican que el número de nidos afectados por condiciones de aguas bajas fue bastante bajo $(<1 \%)$. Un área de humedales presenta aguas bajas una vez cada cinco o diez años y es raro que uno de estos sucesos abarque todo el rango de $R$. sociabilis en Florida. Durante una época de aguas bajas, las aves están en capacidad de moverse hacia otros sitios por lo que relativamente pocas podrían tener bajo éxito reproductivo como consecuencia de la escasez de agua. El manejo dirigido a suprimir estos eventos podría ser innecesario e ir en detrimento del mantenimiento del hábitat a largo plazo.

Manuscript received 9 September 2000; accepted 20 April 2001.

${ }^{5}$ Present address: Natural Resources Ecology Laboratory, Colorado State University, Fort Collins, CO 80523-1499, e-mail: vdreitz@nrel.colostate.edu

${ }^{6}$ Present address: Brevard County Natural Resources, 2725 Judge Fran Jamieson Way, Viera, FL 32940.

${ }^{7}$ Present address: U.S.G.S., Forest and Rangeland Ecosystem Science Center, 3200 SW Jefferson Way, Corvallis, OR 97331.

\section{INTRODUCTION}

The tolerance for environmental stochastic events differs among species, with some having life-history strategies that allow greater tolerance than other species. Variability in environmental factors (e.g., temperature and rainfall) can influence life-history traits, and the degree to which each species responds to environmental 
heterogeneity varies by orders of magnitude both temporally and spatially (Rhodes and Odum 1996). For conservation strategies and management decisions it is important to determine the critical environmental factors that influence populations and to what extent populations can adjust to environmental variation (Ricklefs 1973). For many wetland species, hydrology is a key environmental factor that influences life history strategies and thus, the population dynamics of these species (Ogden et al. 1980, Johnson et al. 1991, Cézilly et al. 1995, Sykes et al. 1995).

The Snail Kite (Rostrhamus sociabilis) occurs within the wetlands of central and southern Florida. Reproduction, particularly nest success, of Snail Kites in Florida has been well studied (Beissinger 1986, Sykes 1987, Bennetts et al. 1988, Snyder et al. 1989). Nest success of Snail Kites is highly variable among years and wetland areas (Snyder et al. 1989, Sykes et al. 1995). Water levels, particularly low water conditions associated with droughts, have been the factor most frequently reported to influence nest success (Beissinger 1986, Sykes 1987, Snyder et al. 1989).

Assessments of the environmental factors that influence life-history traits are commonly limited by the spatial and temporal extent of most research. Studies conducted at one or two study sites for one or two years offer little potential to assess variation expressed across broad landscapes over many years. Recent advances in the use of meta-analysis offer some relief from this limitation. Meta-analysis enables one to derive a quantitative summary of data from multiple studies and to assess variation over time and space (Arnqvist and Wooster 1995, Burnham et al. 1996). A major benefit of meta-analysis is that it has an improved control over Type II error because of larger effective sample size (Arnqvist and Wooster 1995). Meta-analysis has been used in a number of ecological studies (Gurevitch et al. 1992, Burnham et al. 1996, Kennedy 1997, Franklin et al. 1999). Only a few of these studies examined the ecology of individual species: the Northern Spotted Owl (Strix occidentalis caurina; Burnham et al. 1996, Franklin et al. 1999) and Northern Goshawk (Accipiter gentilis; Kennedy 1997). Here we conduct a meta-analysis on the nesting success of Snail Kites in central and southern Florida using data collected during studies encompassing more than 22 years. We use this analysis to test for the effect of low water conditions on nest success and to evaluate other potential sources of the spatial and temporal variability in nest success.

\section{METHODS}

Data used for the meta-analysis were obtained from studies that were conducted from 1972 through 1997, excluding 1984, 1985, 1988, and 1989 , in which no data were collected. The studies covered 11 wetland areas (Table 1). These studies differed in the way they defined nest initiation. Some studies (Beissinger 1986, Snyder et al. 1989) considered structures prior to egg laying as the initiation of a nesting attempt. However, pair bonds for this species are not often established during the pre-laying stage. Failures at this stage constitute courtship failure rather than nest failure (Bennetts et al. 1994). Thus, we followed the definitions of Steenhof (1987) and considered a nesting attempt to begin with the laying of the first egg. A nest was considered successful when at least one young reached 24 days (80\% of age of first flight, Steenhof and Kochert 1982). After this time, fledglings begin to leave the nest and may or may not be found in the immediate vicinity of the nest. The Mayfield method (Mayfield 1961, 1975) for estimating nest success was not used because data for each nest visit were not available for most studies. The Mayfield method takes into account the biases (i.e., overestimation of nest success) associated with not finding a nest on the first day of the nesting period (Hensler and Nichols 1981). The success rate for years and areas for which only one nest $(n=$ 10) was reported cannot be estimated (i.e., success rate $=0$ or 1 ) and were excluded from the analysis.

Previous literature regarding water-level effects on Snail Kites (Beissinger 1986, Sykes 1987, Snyder et al. 1989) have used the term "drought", without defining whether droughts denote low rainfall or low water levels, although the discussions imply the latter. Nor have these authors defined any criteria regarding magnitude, duration, or spatial extent of droughts (Bennetts and Kitchens 1997a, Bennetts et al. 1999). Because water levels in Florida's wetlands have become increasingly disconnected from rainfall as a result of management (Kitchens et al. 2001), we focused on water levels, 
TABLE 1. Data from six sources used to conduct a meta-analysis on nesting success of Snail Kites at 11 wetland areas in Florida, and resulting estimates of nest success $(\hat{S})$ and corresponding standard errors $(S \hat{E}(\hat{S}))$.

\begin{tabular}{|c|c|c|c|c|c|c|c|}
\hline Year & Area $^{a}$ & Type & $\begin{array}{l}\text { Number } \\
\text { of nests }\end{array}$ & $(\hat{\mathrm{S}})^{\mathrm{b}}$ & $S \hat{E}(\hat{S})^{\mathrm{b}}$ & Water ${ }^{c}$ & Source \\
\hline 1972 & Lake Okeechobee & Lake & 3 & 0.33 & 0.27 & -0.20 & Snyder et al. (1989) \\
\hline 1973 & Lake Okeechobee & Lake & 18 & 0.22 & 0.10 & -0.41 & Snyder et al. (1989) \\
\hline 1974 & Lake Okeechobee & Lake & 13 & 0.00 & $\ldots$ d & -1.18 & Snyder et al. (1989) \\
\hline 1975 & Lake Okeechobee & Lake & 15 & 0.00 & - $^{\mathrm{d}}$ & -0.70 & Snyder et al. (1989) \\
\hline 1976 & Lake Okeechobee & Lake & 18 & 0.00 & $-^{d}$ & -0.58 & Snyder et al. (1989) \\
\hline 1977 & Lake Okeechobee & Lake & 13 & 0.15 & 0.10 & -0.28 & Snyder et al. (1989) \\
\hline 1978 & Lake Okeechobee & Lake & 4 & 0.00 & $\ldots \mathrm{d}$ & 1.01 & Snyder et al. (1989) \\
\hline 1978 & WCA-3A & Marsh & 55 & 0.46 & 0.07 & 1.18 & Snyder et al. (1989) \\
\hline 1979 & Lake Okeechobee & Lake & 12 & 0.33 & 0.14 & 0.96 & Snyder et al. (1989) \\
\hline 1979 & WCA-3A & Marsh & 66 & 0.58 & 0.06 & 0.65 & Snyder et al. (1989) \\
\hline 1980 & Lake Okeechobee & Lake & 2 & 0.00 & $\ldots \mathrm{d}$ & 0.68 & Snyder et al. (1989) \\
\hline 1981 & WCA-3A & Marsh & 5 & 0.00 & $-d$ & -1.29 & Snyder et al. (1989) \\
\hline 1982 & $\mathrm{KTOH}$ & Lake & 12 & 0.08 & 0.08 & $0.32^{\mathrm{e}}$ & Snyder et al. (1989) \\
\hline 1983 & OKKIS & Lake & 6 & 0.17 & 0.15 & $1.09^{\mathrm{e}}$ & Snyder et al. (1989) \\
\hline 1983 & WCA-3A & Marsh & 12 & 0.33 & 0.14 & 0.54 & Snyder et al. (1989) \\
\hline 1986 & WCA-3A & Marsh & 107 & 0.26 & 0.04 & 0.76 & Bennetts et al. (1988) \\
\hline 1987 & WCA-3A & Marsh & 210 & 0.44 & 0.03 & 0.39 & Bennetts et al. (1988) \\
\hline 1990 & St. Johns Marsh & Marsh & 26 & 0.08 & 0.05 & 0.96 & Toland (1994) \\
\hline 1991 & St. Johns Marsh & Marsh & 41 & 0.34 & 0.07 & 0.91 & Toland (1994) \\
\hline 1991 & WPBWCA & Marsh & 11 & 0.64 & 0.15 & 0.68 & Mihalik (1994) \\
\hline 1992 & St. Johns Marsh & Marsh & 59 & 0.54 & 0.06 & 0.40 & Toland (1994) \\
\hline 1992 & WCA-2A & Marsh & 15 & 0.47 & 0.13 & -0.83 & Bennetts et al., unpubl. data \\
\hline 1992 & WCA-2B & Marsh & 2 & 0.00 & 0.00 & -0.88 & Bennetts et al., unpubl. data \\
\hline 1992 & WCA-3A & Marsh & 5 & 0.20 & 0.18 & 0.06 & Bennetts et al., unpubl. data \\
\hline 1992 & WPBWCA & Marsh & 14 & 0.79 & 0.11 & -0.65 & Mihalik (1994) \\
\hline 1993 & St. Johns Marsh & Marsh & 43 & 0.35 & 0.07 & 1.21 & Toland (1994) \\
\hline 1993 & WCA-2A & Marsh & 24 & 0.33 & 0.10 & 0.16 & Bennetts et al., unpubl. data \\
\hline 1993 & WCA-2B & Marsh & 6 & 0.50 & 0.20 & 0.75 & Bennetts et al., unpubl. data \\
\hline 1993 & WCA-3A & Marsh & 41 & 0.42 & 0.08 & 1.14 & Bennetts et al., unpubl. data \\
\hline 1993 & WCA-3B & Marsh & 2 & 1.00 & $\ldots \mathrm{d}$ & 1.29 & Bennetts et al., unpubl. data \\
\hline 1993 & WPBWCA & Marsh & 24 & 0.75 & 0.09 & 0.46 & Mihalik (1994) \\
\hline 1994 & Lake Kissimmee & Lake & 30 & 0.50 & 0.09 & 1.42 & Bennetts et al., unpubl. data \\
\hline 1994 & Lake Okeechobee & Lake & 5 & 0.60 & 0.22 & 0.52 & Bennetts et al., unpubl. data \\
\hline 1994 & St. Johns Marsh & Marsh & 4 & 0.25 & 0.22 & 1.10 & Bennetts et al., unpubl. data \\
\hline 1994 & WCA-2B & Marsh & 33 & 0.61 & 0.09 & 1.20 & Bennetts et al., unpubl. data \\
\hline 1994 & WCA-3A & Marsh & 27 & 0.59 & 0.09 & 0.97 & Bennetts et al., unpubl. data \\
\hline 1994 & WPBWCA & Marsh & 6 & 0.00 & - d & 0.55 & Mihalik, unpubl. data \\
\hline 1995 & $\begin{array}{l}\text { Big Cypress National } \\
\text { Preserve }\end{array}$ & Marsh & 17 & 0.53 & 0.12 & 2.04 & Bennetts et al., unpubl. data \\
\hline 1995 & Lake Okeechobee & Lake & 18 & 0.50 & 0.12 & 1.53 & Bennetts et al., unpubl. data \\
\hline 1995 & St. Johns Marsh & Marsh & 19 & 0.21 & 0.09 & 1.03 & Bennetts et al., unpubl. data \\
\hline 1995 & $\begin{array}{l}\text { West Lake Tohope- } \\
\text { kaliga }\end{array}$ & Lake & 11 & 0.64 & 0.15 & 0.41 & Bennetts et al., unpubl. data \\
\hline 1995 & WCA-2A & Marsh & 4 & 0.50 & 0.25 & 0.58 & Bennetts et al., unpubl. data \\
\hline 1995 & WCA-2B & Marsh & 70 & 0.67 & 0.06 & 1.34 & Bennetts et al., unpubl. data \\
\hline 1995 & WCA-3A & Marsh & 33 & 0.42 & 0.09 & 1.02 & Bennetts et al., unpubl. data \\
\hline 1995 & WPBWCA & Marsh & 11 & 0.37 & 0.15 & 1.25 & Mihalik, unpubl. data \\
\hline 1996 & $\begin{array}{l}\text { Big cypress National } \\
\text { Preserve }\end{array}$ & Marsh & 7 & 0.71 & 0.17 & 1.03 & Dreitz et al., unpubl. data \\
\hline 1996 & $\begin{array}{l}\text { Everglades National } \\
\text { Park }\end{array}$ & Marsh & 4 & 0.75 & 0.22 & 0.62 & Dreitz et al., unpubl. data \\
\hline 1996 & Lake Okeechobee & Lake & 22 & 0.36 & 0.10 & 0.84 & Dreitz et al., unpubl. data \\
\hline 1996 & St. Johns Marsh & Marsh & 9 & 0.33 & 0.16 & 0.98 & Dreitz et al., unpubl. data \\
\hline 1996 & $\begin{array}{l}\text { West Lake Tohope- } \\
\text { kaliga }\end{array}$ & Lake & 16 & 0.13 & 0.08 & 1.69 & Dreitz et al., unpubl. data \\
\hline 1996 & WCA-2B & Marsh & 3 & 0.33 & 0.27 & 1.12 & Dreitz et al., unpubl. data \\
\hline 1996 & WCA-3A & Marsh & 60 & 0.48 & 0.06 & 0.99 & Dreitz et al., unpubl. data \\
\hline 1996 & WPBWCA & Marsh & 4 & 0.75 & 0.22 & 0.63 & Mihalik, unpubl. data \\
\hline
\end{tabular}


TABLE 1. Continued.

\begin{tabular}{|c|c|c|c|c|c|c|c|}
\hline Year & Area $^{\mathrm{a}}$ & Type & $\begin{array}{l}\text { Number } \\
\text { of nests }\end{array}$ & $(\hat{\mathrm{S}})^{\mathrm{b}}$ & $S \hat{E}(\hat{S})^{\mathrm{b}}$ & Water ${ }^{c}$ & Source \\
\hline 1997 & Lake Okeechobee & Lake & 3 & 0.00 & $-\mathrm{d}$ & 0.02 & Dreitz et al., unpubl. data \\
\hline 1997 & St. Johns Marsh & Marsh & 22 & 0.18 & 0.08 & 0.54 & Dreitz et al., unpubl. data \\
\hline 1997 & $\begin{array}{l}\text { West Lake Tohope- } \\
\text { kaliga }\end{array}$ & Lake & 28 & 0.11 & 0.06 & 0.45 & Dreitz et al., unpubl. data \\
\hline 1997 & WCA-2B & Marsh & 19 & 0.16 & 0.08 & 0.71 & Dreitz et al., unpubl. data \\
\hline 1997 & WCA-3A & Marsh & 168 & 0.51 & 0.04 & 0.91 & Dreitz et al., unpubl. data \\
\hline \multirow[t]{2}{*}{1997} & WPBWCA & Marsh & & $\begin{array}{l}0.20 \\
\text { mean }\end{array}$ & 0.18 & 0.90 & Mihalik, unpubl. data \\
\hline & & & \multicolumn{2}{|c|}{$n=1541^{f}$} & $\hat{S}=0.41^{\mathrm{f}}$ & & \\
\hline
\end{tabular}

a WCA = Water Conservation Area; $\mathrm{KTOH}=$ Lake Kissimmee and West Lake Tohopekaliga (the number of nests was not reported separately for these areas); OKKIS = Lake Okeechobee and Lake Kissimmee (the number of nests was not reported separately for these areas); WPBWCA = West Palm Beach Water Catchment Area.

b Based on area $\times$ year model.

${ }^{c}$ Minimum annual water levels, measured as the number of standard deviations above or below the annual mean minimum water levels (standard normal).

${ }^{\mathrm{d}}$ Not estimated due to error in convergence.

e Weighted average for the two areas.

f Based on "no effects" model.

rather than rainfall, as indications of low water. Our measure of water level for an area on an annual basis was the variation in mean annual minimum elevation of the water surface relative to mean sea level (Bennetts and Kitchens 1997a, Bennetts et al. 1999). The specific gauges used for each wetland area and the responsible agencies are found in Bennetts and Kitchens (1997a). We used this measure instead of water depth for the following reasons: (1) we were interested in the relative water levels of the entire wetland area among years, (2) ground elevation within areas is highly variable, (3) elevation data are lacking for most areas, and (4) nest-site-specific data were not available for many nests. The number of standard deviations above or below the mean annual minimum was used to account for the differences in elevation among areas (Bennetts and Kitchens 1997a, Bennetts et al. 1999). Consequently, we defined a low water event, equivalent to a "drought", as any period when water level was $\geq 1$ standard deviation below the mean. This categorization corresponds quite well with the qualitative designation of drought years reported in previous studies (Snyder et al. 1989, Beissinger 1995) but is based on quantitative criteria (Bennetts and Kitchens 1997a).

Logistic regression was used to test for the effects of area, year, habitat type (lake or marsh), and water levels on annual nest success. We developed a suite of candidate models based on biological relevance to examine the influence of these effects (Burnham and Anderson 1998). Models were developed in which confounded effects could be compared between two separate models to determine which effect had a greater influence on annual nest success. For example, we did not develop a model in which area and habitat type were both included because habitat type is a component of the area. Also we did not develop a model containing interactions of area, year, and a water variable (i.e., water levels or water conditions) because the water variables are nested within the interaction of area and year.

Our model selection criterion was based primarily on Akaike's Information Criterion (AIC) (Akaike 1973, Shibata 1989, Burnham and Anderson 1998) corrected for small sample sizes $\left(\mathrm{AIC}_{\mathrm{c}}\right.$; Hurvich and Tsai 1989). The goal of model selection is to identify a biologically meaningful model that explains much of the observed variability by including enough parameters to avoid substantial bias, but not so many that precision is lost (Lebreton et al. 1992, Burnham and Anderson 1998). The models were ranked and compared in terms of their ability to explain variation in the empirical data using $\triangle \mathrm{AIC}_{\mathrm{c}}$ (Burnham and Anderson 1998) and $\mathrm{AIC}_{\mathrm{c}}$ weights (Buckland et al. 1997, Burnham and Anderson 1998). The $\Delta \mathrm{AIC}_{\mathrm{c}}$ for a given model is the difference in $\mathrm{AIC}_{\mathrm{c}}$ between the given model and the best (i.e., lowest $\mathrm{AIC}_{\mathrm{c}}$ ) approximating 
model (Burnham and Anderson 1998). Further, to better interpret the relative likelihood of a given model over a set of models, models are normalized (by summing to 1) to be a set of $\mathrm{AIC}_{\mathrm{c}}$ weights (Buckland et al. 1997, Burnham and Anderson 1998). Therefore, the larger the $\Delta$ $\mathrm{AIC}_{\mathrm{c}}$, the smaller the $\mathrm{AIC}_{\mathrm{c}}$ weight, and the less plausible the given model.

Specific effects of interest were tested with likelihood-ratio tests (McCullagh and Nelder 1989). Because annual minimum water levels have been the most frequently hypothesized influence on nest success and are of primary interest for management, we used a generalized coefficient of determination $\left(\bar{R}^{2}\right)$ to estimate how much of the variation in our best approximating model was explained by annual minimum water levels. Such an analysis was first proposed by Cox and Snell (1989) and later modified by Nagelkerke (1991) to determine the proportion of variation explained by a model (e.g., water) relative to another model (e.g., area $\times$ year).

\section{RESULTS}

Based on a model without spatial and temporal variability (i.e., a "no effects" model), the overall proportion of nests $(n=1541)$ that were successful was $0.41 \pm 0.01$ (Table 1). Although this estimate is reasonable for overall success, the analysis indicated that there was considerable spatial and temporal variability in nest success. Based on $\mathrm{AIC}_{\mathrm{c}}$, the most parsimonious model that best explained the data was a model that included area effects, year effects, and an interaction effect among area and year (Table 2). The results also indicated that the spatial and temporal variability in nest success was far greater than can be explained by our measure of annual minimum water levels, either as a categorical response (i.e., drought vs. non-drought) or as a continuous linear response. In addition, the $\mathrm{AIC}_{\mathrm{c}}$ weight (0.99) for this model suggested it was 99\% more likely to be the best approximating model than all other models. The $\mathrm{AIC}_{\mathrm{c}}$ weight for each of the other models was approximately 0.00 . Likelihood-ratio tests between models with water levels as covariates and more general models of individual area and year effects strongly rejected the water-level models whether water levels were considered as a continuous linear $\left(\chi_{55}^{2}=215.3, P<0.001\right)$ or as a categorical (drought vs. non-drought) response $\left(\chi_{56}^{2}\right.$ $=218.4, P<0.001)$. Further, the logistic coef-
TABLE 2. Logistic regression models and their corresponding Akaike Information Criterion $\left(\mathrm{AIC}_{\mathrm{c}}\right.$ ) scores for nesting success. Models are listed in ascending order of $\mathrm{AIC}_{\mathrm{c}}$, with $\triangle \mathrm{AIC}_{\mathrm{c}}$ indicating the difference between each model and the model with the lowest $\mathrm{AIC}_{\mathrm{c}}$ value (i.e., the best model).

\begin{tabular}{|c|c|c|c|}
\hline Model & $\begin{array}{c}\text { Number } \\
\text { of para- } \\
\text { meters }\end{array}$ & $\mathrm{AIC}_{\mathrm{c}}$ & $\Delta \mathrm{AIC}_{\mathrm{c}}$ \\
\hline Year Area Year $\times$ Area & 57 & 1971.15 & 0.00 \\
\hline Year + Area & 33 & 1989.01 & 17.86 \\
\hline Year + Area + Water ${ }^{a}$ & 34 & 1991.08 & 19.93 \\
\hline Year Habitat Year $\times$ Habitat & 29 & 1994.73 & 23.58 \\
\hline Year + Habitat & 23 & 1998.77 & 37.62 \\
\hline Year & 22 & 2010.10 & 38.95 \\
\hline Year $(\text { Trend })^{\mathrm{b}} \times$ Area & 21 & 2011.32 & 40.17 \\
\hline Year + Water ${ }^{\mathrm{a}}$ & 23 & 2011.94 & 40.79 \\
\hline Area + Drought $^{\mathrm{c}}$ & 13 & 2023.13 & 51.98 \\
\hline Area + Water $^{\mathrm{a}}$ & 14 & 2030.99 & 59.83 \\
\hline Year (Trend) ${ }^{\mathrm{b}}$ Area & 14 & 2032.02 & 60.87 \\
\hline Area & 13 & 2035.59 & 64.44 \\
\hline Habitat + Drought ${ }^{c}$ & 2 & 2043.01 & 71.86 \\
\hline Habitat + Water ${ }^{a}$ & 3 & 2045.09 & 73.94 \\
\hline Habitat & 2 & 2056.38 & 85.23 \\
\hline Water ${ }^{\mathrm{a}}$ & 2 & 2072.03 & 100.88 \\
\hline Drought $^{c}$ & 1 & 2073.09 & 101.94 \\
\hline Year (Trend) ${ }^{b}$ & 2 & 2074.35 & 103.20 \\
\hline "No effect"" & 1 & 2092.48 & 121.33 \\
\hline
\end{tabular}

a Standardized water levels considered as a continuous variable.

b Year treated as a linear trend.

c Water level considered as categorical variable more or less than $1 \mathrm{SD}$ away from the mean.

ficient for the effect of water levels, after accounting for year and area effects (model: Year + Area + Water), was $0.04 \pm 0.31 \mathrm{SE}$, indicating the effect did not differ from zero. The data further indicated that our measure of water levels explained only a very small amount of the overall variation in nest success (generalized $\bar{R}^{2}$ $=0.02$ ). The analysis also indicated that the spatial and temporal variability was not well explained by habitat type (lake or marsh) $\left(\chi^{2}{ }_{28}=\right.$ $82.9, P<0.001)$.

\section{DISCUSSION}

The meta-analysis we conducted was not a reanalysis of the original data. It was, instead, a comprehensive analysis of the composite data set. Our results are consistent with previous reports (reviewed by Sykes et al. 1995) that there is substantial spatial and temporal variability in nest success. Our results indicate that the most parsimonious model describing nest success variability is one that includes separate parameter 


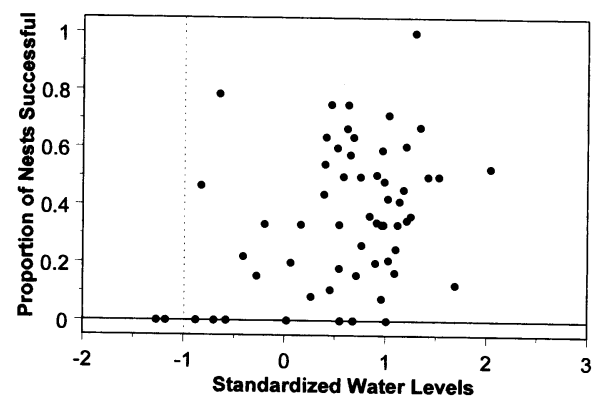

FIGURE 1. Scattergram of Snail Kite nest success and standardized water levels for 11 areas and 22 years, gathered from six previously published studies. Standardized water levels $\geq 1$ SD below the mean $(0)$ were considered low-water events.

estimates for area and year and their interaction. The inclusion of the area $\times$ year interaction term indicates that nest success not only differs among areas and years, but that different areas experience high or low success in different years.

Previous assessments suggest low water levels are the most important environmental factor influencing nest success of Snail Kites (Beissinger 1986, Sykes 1987, Snyder et al. 1989). Based on these previous reports, it might be easy to conclude that the interaction among areas and years represents the variation in water levels over the central and southern Florida landscape. However, our analysis suggested water levels, expressed either as a categorical or a continuous variable, are not good predictors of annual nest success. Models having only water-level effects (either categorical or continuous), in lieu of area and year effects, had among the highest $\mathrm{AIC}_{c}$ scores of all the models considered, indicating that these were the least appropriate based on the principle of parsimony. Similarly, water levels in addition to area and year were rejected based on likelihood-ratio tests. However, this does not imply that low water levels do not influence nest success. We agree with previous authors (Beissinger 1986, Sykes 1987, Snyder et al. 1989) that nest success can be substantially reduced during low water events. The data we reanalyzed are consistent with these previous assertions, as during low water events, nearly all nests failed (Fig. 1). We suggest the consequences of reduced nest success to the population as a whole during low water events are relatively minor and should not dictate long-term management strategies. First, extreme low water events in central and southern Florida occur only once every 5 to 10 years (Duever et al. 1994). Second, it is rare that such events encompass the entire range of Snail Kites in Florida (Bennetts and Kitchens 1997a, 1997b). Lastly, Snail Kites are highly nomadic, moving from one wetland area to another several times a year (Bennetts and Kitchens 2000). Thus, during most low water events birds are capable of moving to alternative wetland areas to breed (Bennetts and Kitchens 1997a, 1997b, Bennetts, Kitchens, and DeAngelis 1998). As a consequence, relatively few birds exhibit low nest success as a result of low water events. Of the data reported here, only 18 of $1541(1 \%)$ of the nests were affected by such low water conditions.

Although the data do not support the hypothesis that low water conditions are a primary influence on nest success, they do not specifically preclude such an effect on other reproductive parameters. Beissinger (1986) suggested that a large proportion of kites did not attempt to nest during low water conditions in 1981. Although his estimate of the breeding population did not use reliable statistical methods (e.g., based on marked individuals), this is a result that one might expect during a widespread low water event (Bennetts and Kitchens 1997b). Bennetts, Golden et al. (1998) used radio-telemetry to estimate the proportion of birds attempting to breed, but their estimate was based on only one year and they too were unable to derive a valid estimate for the effect of water levels. There is insufficient data to conduct a meta-analysis on another reproductive parameter, nest productivity. However, the data suggest that there is substantial spatial and temporal variation in the number of young produced.

Studies of short duration or restricted spatial extent have limited potential to provide insights applicable to an entire population. Such insights come only from study designs spanning the temporal and spatial scales in which a population resides. We were able to extend the inference of independent studies by assessing the variation over time and space through a meta-analysis. Using only one study to measure a real effect, such as water levels, could lead to spurious results. However, combining similar studies allows for separation of real effects from random error, or "noise" (Gurevitch et al. 1992), and in this case we were able to determine that water levels had a small effect on nest success of Snail Kites 
when viewed over longer temporal scales and broader spatial scales.

Some of the unexplained spatial and temporal variation in nest success of Snail Kites may be attributable to several factors. For any species, it is important to recognize that the effect of a single general factor, such as water levels, on a life-history trait becomes difficult to detect when interactions are considered. Snyder et al. (1989) reported nest success was strongly influenced by nest substrate, and Bennetts et al. (1988) found that nest success exhibited strong seasonal differences. These and other factors were not considered in our analysis when summary statistic: $\rightarrow$ were not reported in the literature or raw data were not available. However, provided that data are available, meta-analyses provide a valuable tool that enables a comprehensive analysis of factors influencing nest success or other demographic parameters.

\section{ACKNOWLEDGMENTS}

We thank Mary Beth Mihalik and the West Palm Beach Solid Waste Authority for the use of their unpublished data. We are grateful to Jim Hines, W. L. Kendall, and G. C. White for statistical advice and to Jim Nichols, Don DeAngelis, Paul Sykes, Jr., and an anonymous reviewer for their helpful comments on drafts of this manuscript. This is Florida Agricultural Experiment Station, Journal Series No. R-07080.

\section{LITERATURE CITED}

AKAIKE, H. 1973. Information theory and an extension of the maximum likelihood principle, p. 181-267. In B. Petrov and F. Cazakil [EDS.], Proceedings of the 2nd International Symposium on Information. Theory. Akademiai Kiado, Budapest.

ARNQvist, G., AND D. WoOster. 1995. Meta-analysis: synthesizing research findings in ecology and evolution. Trends in Ecology and Evolution 10:236240.

$\rightarrow$ BeISsinger, S. R. 1986. Demography, environmental uncertainty, and the evolution of mate desertion in the Snail Kite. Ecological Applications 67: 1445-1459.

$\rightarrow$ Beissinger, S. R. 1995. Modeling extinction in periodic environments: Everglades water levels and Snail Kite population viability. Ecology 5:618631.

BennetTs, R. E., M. W. Collopy, And S. R. BeissinGER. 1988. Nesting ecology of Snail Kites in Water Conservation Area 3A. Department of Wildlife and Range Science, University of Florida, Florida Cooperative Fish and Wildlife Research Unit, Technical Report No. 31, Gainesville, FL.

BennetTs, R. E., M. W. Collopy, ANd J. A. Rodgers JR. 1994. The Snail Kite in the Florida Everglades: a food specialist in a changing environment, $p$. 507-532. In S. M. Davis and J. C. Ogden [EDS.],
Everglades: the ecosystem and its restoration. St. Lucie Press, Delray Beach, FL.

Bennetts, R. E., K. Golden, V. J. Dreitz, And W. M. KITCHENS. 1998. The proportion of Snail Kites attempting to breed and the number of breeding attempts per year in Florida. Florida Field Naturalist 26:77-108.

Bennetts, R. E., And W. M. Kitchens. 1997a. The demography and movements of Snail Kites in Florida. Florida Cooperative Fish and Wildlife Research Unit, Technical Report No. 56, Gainesville, FL.

Bennetts, R. E., And W. M. Kitchens. 1997b. Population dynamics and conservation of Snail Kites in Florida: The importance of spatial and temporal scale. Colonial Waterbirds 20:324-329.

BennetTs, R. E., AND W. M. KITCHENS. 2000. Factors influencing movement probabilities of a nomadic food specialist: proximate foraging benefits or ultimate gains from explorations? Oikos 91:459467.

Bennetts, R. E., W. M. Kitchens, And D. L. DeANGELIS. 1998. Recovery of the Snail Kite in Florida: beyond a reductionist paradigm. Transactions of the 63rd North American Wildlife and Natural Resources Conference 63:486-501.

Bennetts, R. E., W. A. Link, J. R. Sauer, and P. W. SYKES JR. 1999. Factors influencing counts in an annual survey of Snail Kites in Florida. Auk 116: 316-323.

Buckland, S. T., K. P. Burnham, and N. H. Augustin. 1997. Model selection: an integral part of inference. Biometrics 53:603-618.

Burnham, K. P., And D. R. Anderson. 1998. Model selection and inference: a practical-theoretic approach. Springer-Verlag, New York.

Burnham, K. P., D. R. ANDERSON, AND G. C. White. 1996. Meta-analysis of vital rates of the Northern Spotted Owl. Studies in Avian Biology 17:92101.

Cézilly, F., V. Boy, R. E. Green, G. J. M. Hirons, AND A. R. JOHNSON. 1995. Interannual variation in Greater Flamingo breeding success in relation to water levels. Ecology 76:20-26.

Cox, D. R., And E. J. SNell. 1989. The analysis of binary data. 2nd ed. Chapman and Hall, London.

Duever, M. J., J. F. MeEder, L. C. MeEder, AND J. M. MCCollom. 1994. The climate of south Florida and its role in shaping the Everglades ecosystem, p. 248-255. In S. M. Davis and J. C. Ogden [EDS.], Everglades: the ecosystem and its restoration. St. Lucie Press, Delray Beach, FL.

Franklin, A. B., K. P. Burnham, G. C. White, R. J. Anthony, E. D. Forsman, C. Schwarz, J. D. Nichols, AND J. Hines. 1999. Range-wide status and trends in Northern Spotted Owl populations. U.S.G.S., Biological Resources Division, unpublished Final Report, Corvallis, OR.

Gurevitch, J., L. L. Morrow, A. Wallace, and J. S. WALSH. 1992. A meta-analysis of competition in field experiments. American Naturalist 140:539572.

Hensler, G. L., AND J. D. Nichols. 1981. The Mayfield method of estimating nesting success: a mod- 
el, estimators and simulation results. Wilson Bulletin 43:42-53.

Hurvich, C. M., AND C.-L.Tsai. 1989. Regression and time series model selection in small samples. Biometrika 76:297-307.

Johnson, A. R., R. E. Green, And G. J. M. Hirons. 1991. Survival rates of Greater Flamingos in the west Mediterranean region, p. 249-271. In C. M. Perrins, J.-D. Lebreton, and G. J. M. Hirons [EDS.], Bird population studies. Oxford University Press, London.

Kennedy, P. L. 1997. The Northern Goshawk (Accipiter gentilis atricapillus): Is there evidence of a population decline? Journal of Raptor Research 31:95-106.

Kitchens, W. M., R. E. Bennetts, and D. L. DeANGELIS. 2001. Linkages between the Snail Kite population and wetland dynamics in a highly fragmented South Florida hydroscape. In J. W. Porter and K. G. Porter [EDS.], Linkages between ecosystems: the south Florida hydroscape. CRC/St. Lucie Press, Delray Beach, FL, in press.

Lebreton, J.-D., K. P. Burnham, J. Clobert, and D. R. ANDERSON. 1992. Modeling survival and testing biological hypotheses using marked animals: a unified approach with case studies. Ecological Monographs 62:67-118.

MAYFIELD, H. 1961. Nesting success calculated from exposure. Wilson Bulletin 73:255-261.

MAYFIELD, H. 1975. Suggestions for calculating nest success. Wilson Bulletin 87:456-466.

McCullagh, P., AND J. A. Nelder. 1989. Generalized linear models. 2nd ed. Chapman and Hall, New York.

Minalik, M. B. 1994. North County Resource Recovery facility wildlife conservation management and bird monitoring program: 1987-1993 Final report. Solid Waste Authority of Palm Beach County, FL.

NAGElKerke, N. J. D. 1991. A note on a general definition of coefficient of determination. Biometrika 78:691-692.

Ogden, J. C., H. W. Kale II, And S. A. Nesbitt. 1980. The influence of annual variation in rainfall and water levels on nesting by Florida populations of wading birds. Transactions of the Linnaean Society of New York 9:115-126.

Rhodes, O. E., JR., AND E. P. Odum. 1996. Spatiotemporal approaches in ecology and genetics: the road less traveled, p. 1-7. In O. E. Rhodes Jr., R. K. Chesser, and M. H. Smith [EDS.], Population dynamics in ecological space and time. University of Chicago Press, Chicago, IL.

RICKLEFS, R. E. 1973. Fecundity, mortality, and avian demography, p. 366-435. In D. S. Farner [ED.], Breeding biology of birds: proceedings of a symposium on breeding bird behavior and reproductive physiology in birds. National Academy of Sciences, Washington, DC.

ShibATA, R. 1989. Statistical aspects of model selection, p. 215-240. In J. C. Williams [ED.], From data to model. Springer-Verlag, New York.

SNYDER, N. R. R., S. R. BEISSINGER, AND R. CHANDLER. 1989. Reproduction and demography of the Florida Everglade (Snail) Kite. Condor 91:300-316.

SteENHOF, K. 1987. Assessing raptor reproductive success and productivity, p. 157-170. In B. A. G. Pendleton, B. A. Milsap, K. W. Cline, and D. M. Bird [EDS.], Raptor management techniques manual. National Wildlife Federation, Washington, DC.

SteEnhof, K., And M. N. Kochert. 1982. An evaluation of methods used to estimate raptor nesting success. Journal of Wildlife Management 46:885893.

SYKES, P. W., JR. 1987. Some aspects of the breeding biology of the Snail Kite in Florida. Journal of Field Ornithology 58:171-189.

SyKes, P. W., JR., R. A. Rodgers JR., AND R. E. BENNETTS. 1995. Snail Kite (Rostrhamus sociabilis). In A. Poole and F. Gill [EDS.], The birds of North America, No. 171. Academy of Natural Sciences, Philadelphia, PA, and the American Ornithologists' Union, Washington, DC.

Toland, B. 1994. Snail Kite ecology and status report of other species of regional concern in the Upper St. Johns Marshes. Final Report, Florida Game and Freshwater Fish Commission, Vero Beach, FL. 